\title{
FLIGHT ACTIVITY AND COLONY STRENGTH IN THE STINGLESS BEE Melipona bicolor bicolor (APIDAE, MELIPONINAE)
}

\author{
HILÁRIO, S. D., ${ }^{1}$ IMPERATRIZ-FONSECA, V. L. ${ }^{2}$ and KLEINERT, A. de M. P. ${ }^{2}$ \\ ${ }^{1}$ Departamento de Zoologia, Instituto de Biociências, USP, CEP 05508-900, São Paulo, SP, Brazil \\ ${ }^{2}$ Departamento de Ecologia Geral, Instituto de Biociências, USP, CEP 05508-900, São Paulo, SP, Brazil \\ Correspondence to: Astrid de Matos Peixoto Kleinert, Departamento de Ecologia Geral, Instituto de \\ Biociências, USP, Rua do Matão, trav. 14, Cidade Universitária, CEP 05508-900, \\ São Paulo, SP, Brazil, e-mail: astridkl@ib.usp.br \\ Received February 11, 1999 - Accepted June 16, 1999 - Distributed May 31, 2000
}

(With 4 figures)

\begin{abstract}
Flight activity of Melipona bicolor bicolor, coming from Cunha $\left(23^{\circ} 05^{\prime} \mathrm{S}, 44^{\circ} 55^{\prime} \mathrm{W}\right)$, Atlantic Forest, was studied in ten colonies, and in two periods: from July to September 1993 and from August to September 1995. The colonies were grouped in weak, medium and strong, according to the diameter of the combs, which can provide a good idea of the number of cells built. 855 observations were accomplished for 5 minutes, every half-hour, from 8 to 18 hours. The total number of bees that entered and left the hive and the number of bees that arrived with mud, pollen and resin, besides the number that went out with debris in that period were counted. It was also registered the temperature and the relative humidity of the air. The total external activity, as well as pollen collection, was maximum in the first hours of the morning, mainly in strong colonies. Weak colonies moved their maximum activity approximately to 12 hours. Pollen collection declined gradually, while mud and resin collection rose; removal of debris was greater in the beginning of the morning and in the end of the afternoon. Flight activity increased as relative humidity of the air rose, being optimum for strong colonies in the range between $80 \%-89 \%$, and for the weakest colonies between $70 \%-79 \%$. The minimum temperature observed for exit of the bees was $11^{\circ} \mathrm{C}$, with optimum temperatures ranging between $17^{\circ} \mathrm{C}$ and $22^{\circ} \mathrm{C}$. The results showed that the general state of the colony influences the different strategies of food collection and that these bees should be adapted to environments of high relative humidity as the Atlantic forest.
\end{abstract}

Key words: stingless bees, flight activity, climate conditions, resource collection.

\section{RESUMO}

\section{A influência do estado da colônia na atividade de vôo do meliponíneo Melipona bicolor} bicolor Lepeletier (Apidae, Meliponinae)

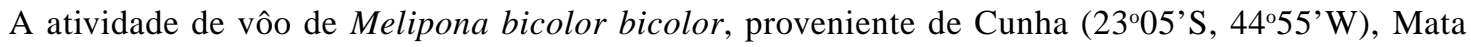
Atlântica, foi estudada em dez colônias, em dois períodos: de julho a setembro de 1993 e de agosto a setembro de 1995. As colônias foram agrupadas em fracas, médias e fortes, segundo o diâmetro dos favos de cria, que pode fornecer uma idéia do número de células de cria construídas. Foram realizadas 855 observações durante 5 minutos, a cada meia hora, das 8 às 18 horas, quando era contado o número total de abelhas que entravam e saíam, o número de abelhas que chegava com barro, pólen e resina, além do número que saía com detritos das colméias naquele período. Foram também registradas a temperatura e a umidade relativa do ar. A atividade externa total, assim como a coleta de pólen, foi máxima nas primeiras horas da manhã, principalmente nas colônias fortes. Colônias fracas deslocaram a atividade máxima para as 12 horas, aproximadamente. A coleta de pólen declinou gradualmente, 
enquanto a coleta de barro e de resina se elevou; a eliminação de detritos foi maior no início da manhã e no final da tarde. A atividade de vôo esteve positivamente correlacionada com a umidade relativa do ar, sendo ótima para colônias fortes na faixa entre 80\%-89\% de umidade relativa, e para as mais fracas entre 70\%-79\%. Quanto à temperatura, o limite mínimo observado para saída das abelhas foi de $11^{\circ} \mathrm{C}$; com temperaturas ótimas entre $17^{\circ} \mathrm{C}$ e $22^{\circ} \mathrm{C}$. Os resultados evidenciam que o estado geral da colônia influencia as diferentes estratégias de coleta de alimento, e que essas abelhas devem estar adaptadas a ambientes de alta umidade relativa como a Mata Atlântica.

Palavras-chave: meliponíneos, atividade de vôo, condições climáticas, coleta de recursos.

\section{INTRODUCTION}

Flight activity of bees is influenced both by internal conditions of the colonies and environment. As several authors pointed out (Iwama, 1977; Fowler, 1978; Kleinert-Giovannini, 1982; Guibu \& Imperatriz-Fonseca, 1984; Imperatriz-Fonseca et al., 1985; Kleinert-Giovannini \& Imperatriz-Fonseca, 1986; Heard \& Hendrikz, 1993), temperature, relative humidity, light intensity, rainfall and wind speed influence the flight activity of stingless bees, although not always with the same intensity. Other important factors would be especially attractive: flowerings, swarming, etc.

The number of individuals in each of the colonies allows its characterization as weak, medium or strong that, for its time, is the result of the interaction of several factors, both internal and external. Camillo-Atique $(1974,1977)$ verified the influence of the strength of the colonies in the behavior of Melipona rufiventris and Friesella schrottkyi. Lacerda et al. (1991) discussed for Geotrigona inusitata behavioral changes in weak, medium and strong colonies based on the variation of the population size of the nests, having mentioned alterations in the workers size and in the flight activity, although this last aspect has not been quantified. Kleinert-Giovannini \& Imperatriz-Fonseca (1986) had already verified that external activity could be influenced by the strength of the colony. Ramalho et al. (1994) and Ramalho et al. (1998) analyzed the relationship among workers size and weight of the pollen load brought into the colony in several species of stingless bees, including Melipona bicolor bicolor. They verified that the smaller bees carried more pollen in each trip than the larger ones, and that bees of weak colonies also brought more pollen in each trip in relation to the weight than bees of strong colonies. Lacerda et al. (1991) also mentioned that weak colonies of
Geotrigona inusitata produced smaller bees than the strong ones.

\section{MATERIAL AND METHODS}

Melipona bicolor is a species that is characterized by polygyny, rare among eusocial bees. It nests close to the soil, next to the roots or the trunks of trees. It is found from Rio Grande do Sul, Paraguay and Argentina (Misiones) until the states of Minas Gerais and Espírito Santo (Nogueira-Neto, 1970).

Ten colonies of Melipona bicolor bicolor Lepeletier were used (from now on denominated from M1 to M10), maintained at the Bee Laboratory of the Department of Ecologia Geral, Instituto de Biociências of the University of São Paulo $\left(23^{\circ} 33^{\prime} \mathrm{S}, 46^{\circ} 43^{\prime} \mathrm{W}\right)$. The colonies were classified as strong, medium and weak, according to the mean diameter of the combs: strong-M1, M2, M5, M6, M7; medium - M3, M4; weak - M8, M9, M10 (Table 1). As observed by Kleinert-Giovannini (1989) for Melipona marginata, the diameter of the combs can provide a good idea of the general state of the colony. A total of 855 observations were made. The total number of bees that entered and left the hive, besides the material they carried (pollen, resin, mud, debris), for 5 minutes, at every half-hour, from 8 to 18 hours, were counted. Air temperature and relative humidity were also registered before each count.

The observations were made in two periods: colonies M1 to M7 were observed from July to September 1993, and colonies M8 to M10, from August to September 1995.

\section{RESULTS}

Data show that the number of bees in weak, medium and strong colonies is very different. 
Forager's activity is reflected in the nests' entrances of Melipona bicolor. Colonies with many foragers throw the nest drops of loamy water away, which results from the control of the nest internal humidity, through the dehydration of the nectar. This material helps to form the typical entrance of the species, which gets to be with big areas of mud in its lower part. Medium colonies present less elaborated entrances, and in the weak colonies the bees practically do not work in the entrances of the colonies. Another aspect is related with the workers size of the strong, medium and weak nests. As well as it was observed by Camillo-Atique (1974) in Melipona rufiventris, by Ramalho et al. (1998) in Melipona quadrifasciata and Melipona bicolor, the size of the bees varies a lot in strong, medium and weak colonies. Three averages were obtained: average of the weak colonies (MW), of the medium colonies (MM) and of the strong colonies (MS). A fourth average was obtained starting from these three and represents the average of flight activity for this species (MA). In general, flight activity was maximum for the average of the species at $18^{\circ} \mathrm{C}$. Strong colonies reached a peak of activity at $18^{\circ} \mathrm{C}$, medium ones at $20^{\circ} \mathrm{C}$ and the weak colonies at $22^{\circ} \mathrm{C}$. The optimum temperature oscillated from $16^{\circ} \mathrm{C}$ to $26^{\circ} \mathrm{C}$. The minimum temperature in that there was external movement of bees was of $11^{\circ} \mathrm{C}$, in colonies $\mathrm{M} 2$ and M3. Effective external activity (the lowest temperature where all the colonies presented external activity) happened at $16^{\circ} \mathrm{C}$ (Fig. 1).

TABLE 1

Average diameter of combs of colonies of Melipona bicolor in relation to its strength.

\begin{tabular}{|l|c|c|}
\hline Colonies & Strength & Average diameter of combs \\
\hline M1, M2, M5, M6, M7 & strong & $9.8 \pm 1.0$ \\
\hline M3, M4 & medium & $6.3 \pm 0.3$ \\
\hline M8, M9, M10 & weak & $3.3 \pm 1.0$ \\
\hline
\end{tabular}

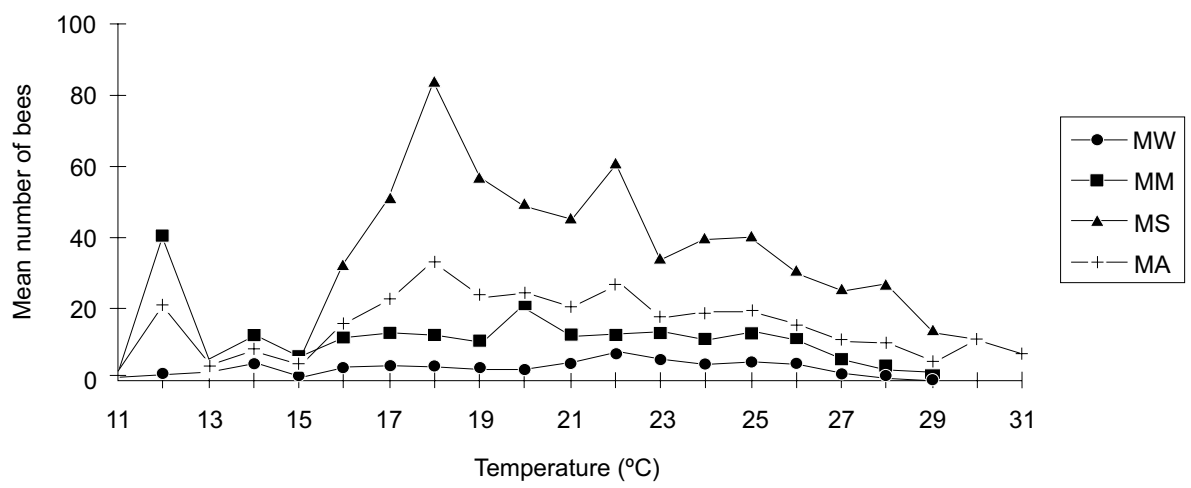

Fig. 1 - Flight activity of Melipona bicolor bicolor related to temperature. MW = average of weak colonies; MM = average of medium colonies; MS = average of strong colonies; MA = average for the species.

Strong colonies had maximum flight activity between $80 \%$ and $89 \%$ of relative humidity. Weak and medium colonies reached a peak of activity between $70 \%$ and $79 \%$. External activity of the species was more frequent between $80 \%-89 \%$. A wide range of flight activity in relation to relative humidity was placed between $60 \%$ and $89 \%$ (Fig. 2). Flight activity of Melipona bicolor bicolor was greater between 8 and 12 hours. For strong colonies, the peak of activity was at 8 hours, declining gradually along the day, although no observations were made earlier. 


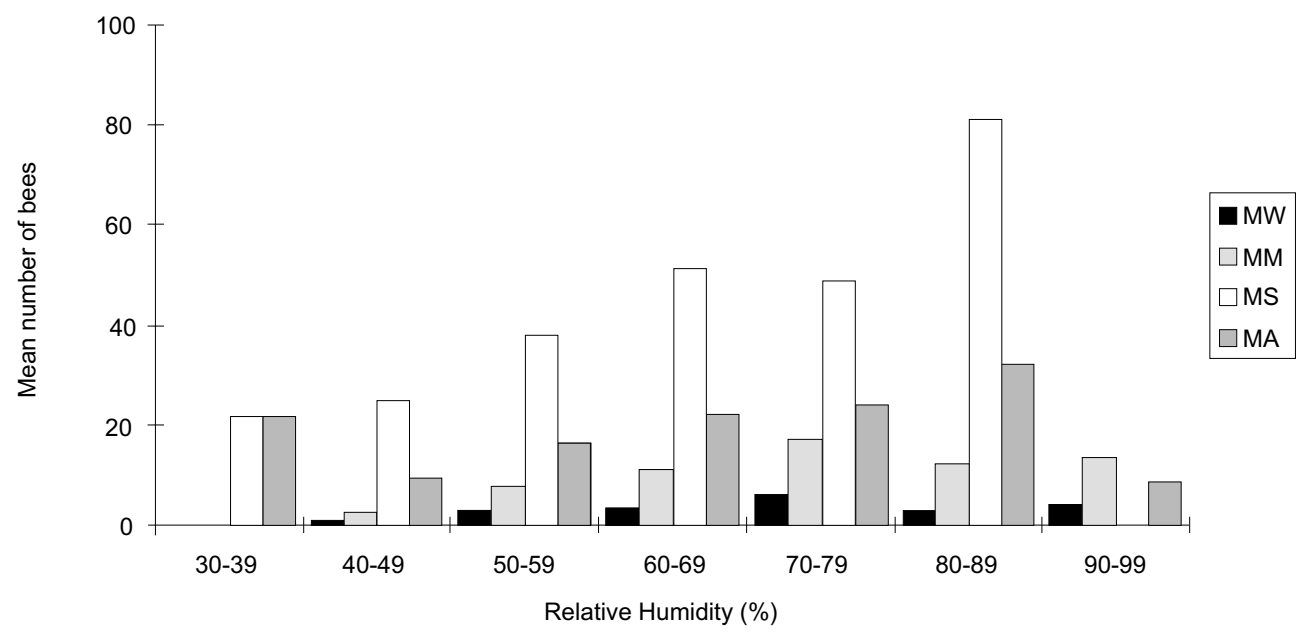

Fig. 2 - Flight activity of Melipona bicolor bicolor related to relative humidity (\%). MW = average of weak colonies; $\mathrm{MM}=$ average of medium colonies; $\mathrm{MS}=$ average of strong colonies; $\mathrm{MA}=$ average for the species.

Medium colonies reached its peak at 9 hours. On the other hand, weak colonies presented a peak of external movement at 12 hours, with a more intense activity between 12 and 14 hours (Fig. 3).

Pollen collection was higher in the first hours of the morning, decaying along the day. On the other hand, mud and resin collection grew gradually reaching its peak at dusk. The debris elimination was higher in early morning and at late afternoon (Fig. 4).

Table 2 shows a summary of the data of Melipona bicolor bicolor presented in this work, as well as of another species previously studied for comparison.

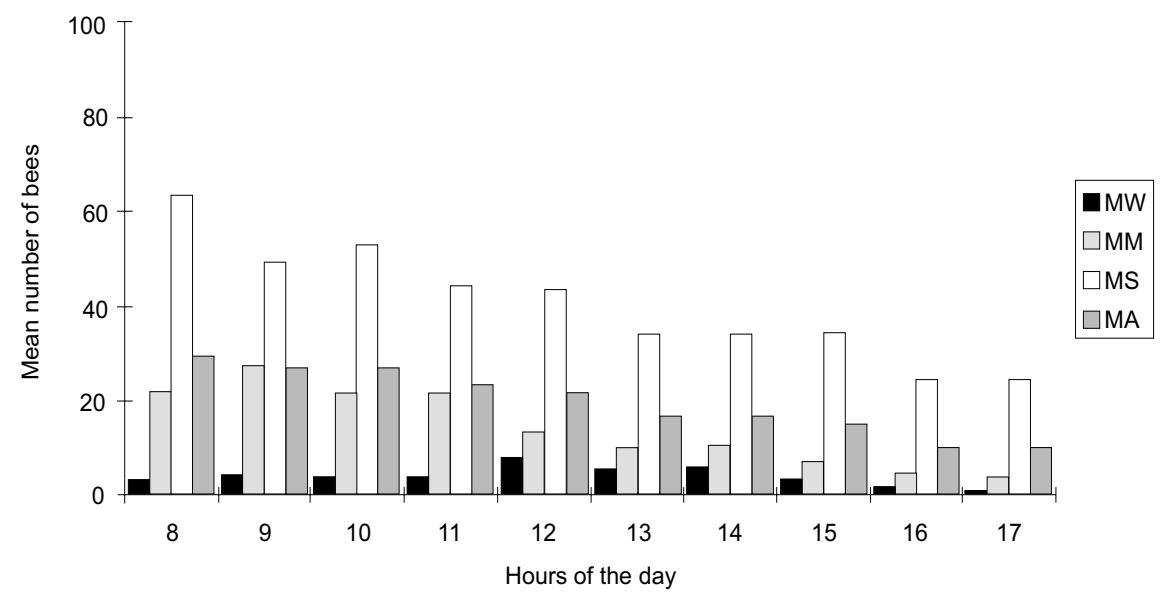

Fig. 3 - Flight activity of Melipona bicolor bicolor related to hours of the day. MW = average of weak colonies; MM = average of medium colonies; MS = average of strong colonies; MA = average for the species. 


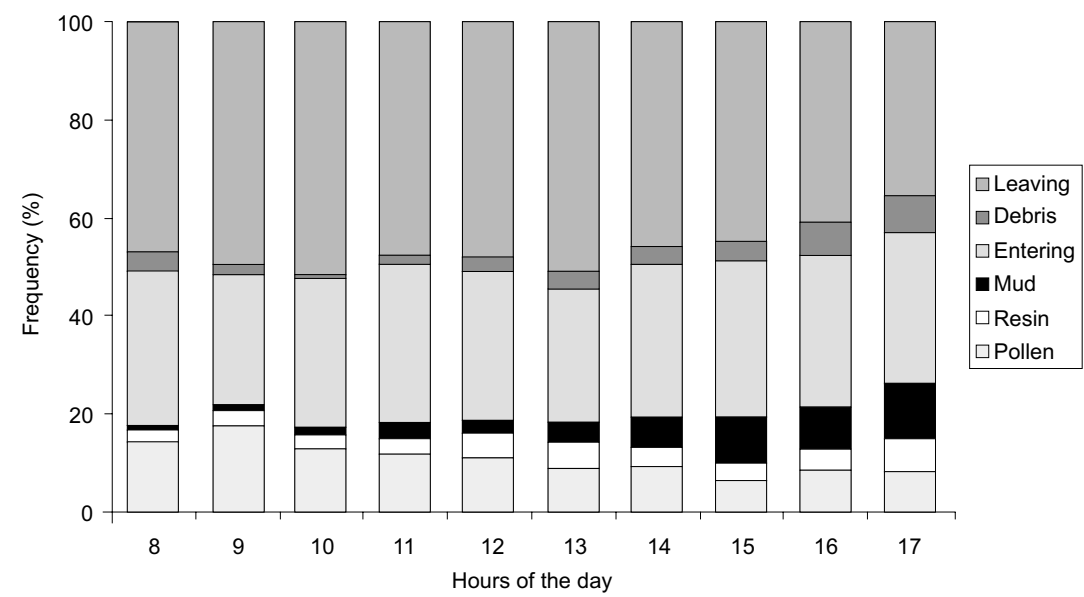

Fig. 4 - Flight activity of Melipona bicolor bicolor in the different hours of the day showing the percentages of bees entering the hive with pollen; resin; mud; nectar, water or without any material (same category); and leaving the hive with debris and without any material.

TABLE 2

Climate conditions for flight activity in some species of stingless bees.

\begin{tabular}{|c|c|c|c|c|c|c|}
\hline Species & $\begin{array}{c}\mathrm{T}^{\prime \prime} \mathrm{C} \text { for } \\
\text { the } \\
\text { beginning } \\
\text { of } \\
\text { flight } \\
\text { activity }\end{array}$ & $\begin{array}{c}\text { Effective } \\
\text { flight } \\
\text { activity }\end{array}$ & $\begin{array}{l}\text { Optimal } \\
\mathrm{T}^{\circ} \mathrm{C} \\
\text { range }\end{array}$ & $\begin{array}{l}\text { Optimal } \\
\text { R.H. }(\%) \\
\text { range }\end{array}$ & $\begin{array}{l}\text { Optimal time } \\
\text { (hours) range }\end{array}$ & Authors \\
\hline Plebeia saiqui & $16-18$ & 18 & $26-32$ & $35-90$ & $10-14$ & Oliveira (1973) \\
\hline Plebeia droryana & $17-19$ & 19 & $22-32$ & $25-90$ & $13: 30-16$ & Oliveira (1973) \\
\hline $\begin{array}{l}\text { Tetragonisca } \\
\text { angustula } \\
\text { angustula }\end{array}$ & $17-24$ & - & $20-30$ & $30-70$ & $11-13$ & Iwama (1977) \\
\hline Plebeia emerina & $16-22$ & 19 & $21-27$ & $40-70$ & $13-14: 30$ & Kleinert-Giovannini (1982) \\
\hline $\begin{array}{l}\text { Melipona } \\
\text { quadrifasciata } \\
\text { quadrifasciata }\end{array}$ & 13 & - & $14-16$ & - & $7-11$ & $\begin{array}{c}\text { Guibu \& Imperatriz-Fonseca } \\
(1984)\end{array}$ \\
\hline Plebeia remota & $16-18$ & 18 & $22-29$ & $60-84$ & $11-15$ & $\begin{array}{l}\text { Imperatriz-Fonseca et al. } \\
(1985)\end{array}$ \\
\hline $\begin{array}{l}\text { Melipona } \\
\text { marginata } \\
\text { marginata }\end{array}$ & $14,16-17$ & - & $19-30$ & $40-70$ & $11-13$ & $\begin{array}{l}\text { Kleinert-Giovannini \& } \\
\text { Imperatriz-Fonseca (1986) }\end{array}$ \\
\hline $\begin{array}{l}\text { Melipona } \\
\text { marginata } \\
\text { obscurior }\end{array}$ & $17-18$ & - & $21-28$ & $40-70$ & $11-13$ & $\begin{array}{l}\text { Kleinert-Giovannini \& } \\
\text { Imperatriz-Fonseca (1986) }\end{array}$ \\
\hline Partamona helleri & 14 & - & $15-24$ & - & $\begin{array}{c}4: 30-8: 30 \\
\text { (summer months) } \\
5: 40-9 \\
\text { (winter months) }\end{array}$ & Azevedo (1997) \\
\hline $\begin{array}{l}\text { Schwarziana } \\
\text { quadripuntacta } \\
\text { quadripuntacta }\end{array}$ & 14 & 17 & $21-26$ & $60-99$ & $8-13$ & $\begin{array}{c}\text { Imperatriz-Fonseca \& } \\
\text { Darakjian (1994) }\end{array}$ \\
\hline $\begin{array}{l}\text { Melipona bicolor } \\
\text { bicolor }\end{array}$ & $11-16$ & 16 & $16-26$ & $60-89$ & $8-12$ & This study \\
\hline
\end{tabular}




\section{DISCUSSION}

Several abiotic factors influence the activity of the bees and among them temperature has been mentioned as the most important (Corbet et al., 1993). However, the activity of some species are limited by the relative humidity, as for example Plebeia emerina, that doesn't go out of its nests with relative humidity higher than $70 \%$ (KleinertGiovannini, 1982). Still some species prefer to leave in the first hours of the morning, while others have its maximum activity in the afternoon (Table 2). Gathering strategies of the several species and floral preferences should influence in this timing. Besides, the physiology of the species also aids in the determination of the limits of this "environmental window" where flight conditions are optimum or allowed.

Food availability suffers variations due to environmental alterations related to temperature, relative humidity, light intensity, wind speed and rainfall variation. These cycles can be daily and/ or seasonal, influencing the behavior of the bees, both inside the hives as in the external activity.

Käpylä (1974) marked that the external activity depends on the body size of the insects, because larger species fly in lower temperatures and light intensities than smaller ones, demonstrating a better capacity to absorb heat. Corbet et al. (1993) mentioned an optimum range for flight activity of the species of social bees, important of being known to allow the use of these species in pollination projects in different areas. An additional consideration is that these "windows" where the external activity is allowed or it is optimum should influence directly the distribution of nests and its relative abundance in a given area. Thus, it is common the occurrence of the same species of social bees in areas of similar climate. Under this focus, it is important to know the limits and the preferences for flight activity for the several species of social bees.

As was already cited, Melipona bicolor bicolor began its external activity in temperatures between $11^{\circ} \mathrm{C}$ and $16^{\circ} \mathrm{C}$, and effective external activity happened in a temperature of $16^{\circ} \mathrm{C}$. Imperatriz-Fonseca et al. (1985) attributed the temperature variation to the beginning of flight activity to the variation of workers size of Plebeia remota.
Heard \& Hendrikz (1993) studied the influence of climatic factors on the external activity of Trigona carbonaria in Australia. They considered temperature and light intensity as the most important factors determining flight activity of these bees. The minimum temperature for this Trigona was $18^{\circ} \mathrm{C}$ and relative humidity didn't show any significant effect. Azevedo (1997) also verified the same for the flight activity of Partamona helleri.

Iwama (1977), studying Tetragonisca angustula, observed that flight activity increased with the decrease of relative humidity. Oliveira (1973), working with Plebeia saiqui and Plebeia droryana, obtained a wide range of relative humidity in which these bees came out and she also noticed a decrease in the external activity in ranges of relative humidity higher than $90 \%$. For Plebeia emerina, Kleinert-Giovannini (1982) observed that flight activity decreased when relative humidity reached $70 \%$, even when other factors were in good conditions. Imperatriz-Fonseca et al. (1985) verified for Plebeia remota a sudden decrease in flight activity at 90\%. Guibu \& Imperatriz-Fonseca (1984) found a positive correlation between flight activity and relative humidity for Melipona quadrifasciata quadrifasciata, as verified for Melipona bicolor bicolor. These two species of bees live in wooden habitats of high relative humidity, with constant fogs.

For Melipona bicolor bicolor it is clear the tendency of food gathering in the first hours of the morning, being its activity curve similar to that observed for Melipona quadrifasciata quadrifasciata (Guibu \& Imperatriz-Fonseca, 1984).

Bruijn \& Sommeijer (1997) marked a temporal division for nectar, pollen and resin collection in Melipona beecheii and M. fasciata, being its peaks very different in time. Colonies of Melipona bicolor bicolor behaved in the same way. The peak of pollen collection happened in the early morning and the peaks of mud and resin collection happened in the twilight. The exit of the colony with debris had two peaks: one in the first hours of the morning and another at twilight. Sommeijer et al. (1983) and Roubik (1989), noticed a second late peak for pollen collection. Roubik (1989) suggested that the late pollen collection should be relatively evident in a habitat poor in foragers. In this study, where a great number of foragers were presented in the habitat 
no late peak of pollen collection was observed. Roubik (op. cit.) attributed the morning peak of pollen collection to resource availability. Pollen is in general abundantly available in the first hours of the morning, but it becomes scarce in the afternoon, as a result of foraging by bees. In this way, the activity patterns of pollen gathering pretend to have developed starting from a preemptive competition under stress. Bruijn \& Sommeijer (1997) suggested that the morning peak of foraging in Melipona can be considered adaptive, since the preemptive competition of the pollen foragers had as reward the collection the earlier as possible. In the tropical region, pollen availability is not a limiting factor, but an intraspecific competition can occur, involving weak, medium and strong colonies. Pollen collection happened earlier in strong colonies than in medium and weak ones. In fact, considering flight activity of stingless bees as a whole, the larger species not just fly earlier than the smallest ones, as foragers of strong colonies come out earlier than those of the weak colonies of the same species (Lecomte, 1968). Heinrich \& Raven (1972) stand out the fact that species with larger bees that leave the hive earlier or in lower temperatures have a larger energy expense, but on the other hand, they obtain larger caloric reward than those that arrive later.

Temperature seems to be the most important environmental factor about the external activity of the bees (Corbet et al., 1993). However, Oliveira (1973) noticed a fall in flight activity when the days passed from sunny to cloudy, although temperature had increased. She also observed that light, separately, did not determine the work of the bees when the temperature was not favourable. Iwama (1977) pointed temperature, proceeded by light intensity and relative humidity, as important factors in the effective flight of Tetragonisca angustula, being the interaction between temperature and light intensity the main determinant of flight activity, because bees did not leave the hives in low temperatures, even with appropriate light intensity. Kleinert-Giovannini (1982) observed that Plebeia emerina did not go out with low temperatures, in spite of favourable relative humidity (50\%-70\%).

The external activity of Melipona bicolor bicolor happened mainly in the morning period, when relative humidity was higher and temperature and light intensity were more moderate. Data of weak, medium and strong colonies showed very different results, and the need to study several colonies when we want to understand the limits of the flight capacity of social bees.

Acknowledgment - We wish to thank CNPq (National Research Council) for the grant (130711/98-5) given to the first author.

\section{REFERENCES}

AZEVEDO, G. G. 1997, Atividade de vôo e determinação do número de instares larvais em Partamona helleri (Friese) (Hymenoptera, Apidae, Meliponinae). MSc. Dissertation. Departamento de Biologia, UFV, Viçosa, $64 \mathrm{p}$.

BRUIJN de, L. L. M. \& SOMMEIJER, M. J., 1997, Colony foraging in different species of stingless bees (Apidae, Meliponinae) and the regulation of individual nectar foraging. Insectes Sociaux, 44: 35-47.

CAMILLO-ATIQUE, C., 1974, Variabilidade do comportamento de Melipona rufiventris rufiventris (Hymenoptera, Apoidea). MSc. Dissertation. Departamento de Genética, Faculdade de Medicina, USP, Ribeirão Preto, 147p.

CAMILLO-ATIQUE, C., 1977, Estudo da variabilidade etológica de Friesella, incluindo a caracterização de espécies crípticas (Hym., Apidae). Rev. Brasil. Biol., 49(4): 999-1001.

CORBET, S. A., FUSSELl, M., AKE, R., FRASER, A., GUNSON, C., SAVAGE, A. \& SMITH, K., 1993, Temperature and pollination activity of social bees. Ecological Entomology, 18(1): 17-30.

FOWLER, H. G., 1978, Responses by a stingless bee to a subtropical environment. Rev. Biol. Trop., 27: 111118.

GUIBU, L. S. \& IMPERATRIZ-FONSECA, V. L., 1984, Atividade externa de Melipona quadrifasciata Lepeletier (Hymenoptera, Apidae, Meliponinae). Ciên. e Cult., 36 supl. (7): 623.

HEARD, T. A. \& HENDRIKZ, J. K., 1993, Factors influencing flight activity of colonies of the stingless bee Trigona carbonaria (Hymenoptera, Apidae). Australian Journal of Zoology, 41(4): 343-353.

HEINRICH, B. \& RAVEN, P. H., 1972, Energetics and pollination ecology. Science, 176(4035): 597-602.

IMPERATRIZ-FONSECA, V. L., KLEINERT-GIOVANNINI, A. \& PIRES, J. T., 1985, Climate variations influence on the flight activity of Plebeia remota Holmberg (Hymenoptera, Apidae, Meliponinae). Rev. Brasil. Ent., 29(3/4): 427-434.

IMPERATRIZ-FONSECA, V. L. \& DARAKJIAN, P., 1994, Flight activity of Schwarziana quadripunctata quadripunctata (Apidae, Meliponinae): influence of environmental factors. Abstracts. International Behavioural Ecology Congress, Nottingham (U.K.), p.86. 
IWAMA, S., 1977, A influência dos fatores climáticos na atividade externa de Tetragonisca angustula (Apidae, Meliponinae). Bolm. Zool. Univ. S. Paulo, 2: 189-201.

KÄPYLÄ, M., 1974, Diurnal flight activity in a mixed population on Aculeata (Hym.). Annls. Ent. Fenn., 40(2): 62-9.

KLEINERT-GIOVANNINI, A., 1982, The influence of climatic factors on flight activity of Plebeia emerina Friese (Hymenoptera, Apidae, Meliponinae) in winter. Rev. Brasil. Ent., 26(1): 1-13.

KLEINERT-GIOVANNINI, A., 1989, Mecanismos de controle reprodutivo em Melipona marginata Lepeletier (Apidae, Meliponinae). PhD. Thesis. Departamento de Zoologia, Instituto de Biociências, USP, São Paulo, $145 \mathrm{p}$.

KLEINERT-GIOVANNINI, A. \& IMPERATRIZ-FONSECA, V. L., 1986, Flight activity and responses to climatic conditions of two subspecies of Melipona marginata Lepeletier (Apidae, Meliponinae). J. Apic. Res., 25(1): 3-8.

LACERDA, L. M., ZUCCHI, R. \& ZUCOLOTO, F. S., 1991, Colony condition and bionomic alterations in Geotrigona inusitata (Apidae, Meliponinae). Acta Biol. Par., 20(1,2,3,4): 109-123.

LECOMTE, J., 1968, Le comportement de butinage. In: R. Chauvin, Traité de biologie de l'abeille. Paris. Masson \& Cie., v. 2: 402-415.
NOGUEIRA-NETO, P., 1970, A criação de abelhas indígenas sem ferrão. Editora Chácaras e Quintais, São Paulo, 365p.

OLIVEIRA, M. A. C., 1973, Algumas observações sobre a atividade externa de Plebeia saiqui e Plebeia droryana. MSc Dissertation. Dep. Zoologia, Instituto de Biociências, USP, São Paulo, 79p.

RAMALHO, M., GIANNINI, T. C., MALAGODI-BRAGA, K. S. \& IMPERATRIZ-FONSECA, V. L., 1994, Pollen harvest by stingless bee foragers (Hymenoptera, Apidae, Meliponinae). Grana, 33: 239-244.

RAMALHO, M., IMPERATRIZ-FONSECA, V. L. \& GIANNINI, T. C., 1998, Within-colony variation of foragers' size and pollen load capacity in stingless bees (Apidae, Hymenoptera). Apidologie, 29: 221-228.

ROUBIK, D. W., 1989, Ecology and Natural History of Tropical Bees. Cambridge University Press, New York, $514 \mathrm{p}$.

SOMMEIJER, M. J., de ROOY, G. A., PUNT, W. \& de BRUIJN, L. L. M., 1983, A comparative study of foraging behaviour and pollen resources of various stingless bees (Hym., Meliponinae) and honey bees (Hym. Apinae) in Trinidad, West-Indies. Apidologie, 14: 205-224. 